\title{
Application of SWAT Model for Estimation of Runoff in Pindwara Watershed and Assessment of its Feasibility
}

\author{
Harsh Upadhyay", H.K. Mittal, Manjeet Singh and J.G. Hirapara \\ Department of Soil and Water Engineering, CTAE, MPUAT, Rajasthan, India \\ *Corresponding author
}

\section{A B S T R A C T}

\section{Keywords}

SWAT, R ${ }^{2}$, NSE,

Digital elevation

Models,

Simulations

Article Info

Accepted:

24 May 2019

Available Online:

10 June 2019
Runoff estimation is a key factor in the design of soil and water conservation structures to prevent land degradation and erosion. In the present study, the Soil and Water Assessment Tool (SWAT) model was used to estimate the runoff in Pindwara watershed situated in the Sirohi district of Rajasthan and spanning over an area of about $1428 \mathrm{~km}^{2}$. Temporal weather data of rainfall and temperature, digital elevation models, soil data, land use land cover imagery was provided to the model as input to estimate runoff at the watershed outlet. The simulations were carried out for a period of 12 years from 2001 to 2012 with initial two years set up as warm-up period. The estimated runoff was compared to the observed runoff for a period of 8 years from 2003 to 2010. SWAT simulated average annual total runoff of $277.57 \mathrm{~mm}$ out of which, $174.96 \mathrm{~mm}$ of surface runoff, $15.55 \mathrm{~mm}$ of lateral flow and $87.06 \mathrm{~mm}$ of return flow was generated. The $\mathrm{R}^{2}$ and NSE values of the simulation were 0.465 and 0.402 . The model was not found fit for direct field application and required calibration and validation before incorporating it for a watershed-scale application.

\section{Introduction}

Land and water are the two most basic yet essential components in agriculture. However, these two natural resources are also the ones that are most subjected to deficiency, deterioration and degradation. Surface runoff is a key factor for driving many watershed processes especially erosion. In absence of proper soil and water conservation measures, erosion would slowly, yet surely, lead to formation of gullies and ravines upon the land, thus decreasing the area available for agriculture. The design criteria of all soil and water conservation structures that are constructed to tackle the problem of soil erosion due to surface runoff, accounts for the amount of surface runoff that is generated from the rainfall in the form of either discharge or depth of runoff.

Therefore, runoff estimation is a key process in the design of soil and water conservation structures. There are several mathematical, empirical and physical models that have been employed for the purpose of runoff estimation. The SWAT model is one of the most popular and commonly used models for runoff estimation. 
Rosenthal et al., (1995) used SWAT to evaluate water yields from the 8927 square kilometers area of Lower Colorado River Basin in Texas. Measured outflow from an upstream reservoir was used as an initial input to the model. The authors reported a significant relationship between observed and simulated monthly streamflow using the SWAT model even without calibration.

Srinivasan et al., (1998) used the SWAT model to simulate the hydrology in the Richland-Chambers watershed of the Trinity River basin in Texas. The stream flow was calibrated and validated for the watershed. The calibration conducted in the study was minimal and in general and the monthly streamflow rates predicted by SWAT corresponded very well with the observed values.

Pindwara watershed is situated at the southern corner of the state of Rajasthan in the district of Sirohi. It can be considered as one of the most representative of all the watersheds in Rajasthan as it encompasses a wide variety of features, be it weather or topography. The state of Rajasthan suffers from the problem of severe water crisis in most of the region as well as occurrence of flash floods in some areas. It lacks a good gauge network that can provide valuable data about the runoff conditions in the state. Therefore, modeling can be viewed as an approach for runoff estimation in ungauged watersheds. Keeping these facts into consideration, the study aimed to assess the feasibility of SWAT model for estimation of runoff in Pindwara watershed.

\section{Study area}

The selected area known as Pindwara watershed, coded by the Micro-watershed Atlas of India as Watershed "5H3E5", is situated in the eastern region of Sirohi district in Rajasthan, about 435 kilometres from the capital city of Jaipur, and is bounded by the latitudes $24^{\circ}$ 54' $42^{\prime \prime}$ and $24^{\circ} 23^{\prime}$ 06" and longitudes $73^{\circ} 09^{\prime} 39^{\prime \prime}$ and 72 41' 44". The watershed spans over an area of 1428 square kilometers, which is covered by the GT sheet numbers "45D10" and "45D14" under the authority of Survey of India.

The topography in most of the central region of the area is plane with a significantly undulating topography due to the tracts of hilly region around the boundary of the area. The average annual rainfall of the area is 613 millimeters, most of which is received during the monsoon season in the months of late June to mid-September. The mean monthly temperature of the study area varies from a maximum of $32.4^{\circ} \mathrm{C}$ to a minimum of $19.5^{\circ} \mathrm{C}$ with a mean daily temperature of about $26^{\circ} \mathrm{C}$. The outline map of the Pindwara watershed has been shown in Figure 1.

\section{Data acquisition}

The weather data for the period of 2001 to 2012 was obtained from CFSR (Climate Forecast System Reanalysis) weather database. Digital elevation model of the study area having a $90 \mathrm{~m}$ resolution was downloaded from USGS (United States Geological Survey) Earth Explorer. The soil map was extracted from digital soil map of the world downloaded from FAO (Food and Agriculture Organization) database. Land cover imagery was obtained from Bhuvan geo-portal developed by ISRO, Government of India in 2009.

Land use land cover maps were prepared using ArcGIS 10.4. The slope map was derived from the DEM. The runoff data for the period of 2003 to 2010 was downloaded from India-WRIS (Water Resource Information System) database maintained by NRSC, India. 


\section{Materials and Methods}

SWAT model is a physically based, continuous, semi-distributed, process based basin scale model that works on a daily time step. The SWAT model can be said to consist of two major components - (1) Land phase and, (2) Routing phase. The land phase component of SWAT deals with eight major parameters which are hydrology, weather, sedimentation, soil temperature, crop growth, nutrients, pesticides and agricultural management. The routing phase component of SWAT is concerned with the movement, channel flow and changes of all the parameters associated with the land phase component of SWAT. The hydrologic computations in the SWAT model are based on the water balance equation.

$S W_{t}=S W_{0}+\sum_{i=1}^{t}\left(R_{\text {day }}-Q_{\text {surf }}-E_{\alpha}-w_{\text {sesp }}-Q_{g w}\right)$

Where,

$S W_{t} \quad=$ Final soil water content $\left(\mathrm{mm} \mathrm{H}_{2} \mathrm{O}\right)$

$S W_{0}=$ Initial soil water content on day i $\left(\mathrm{mm} \mathrm{H}_{2} \mathrm{O}\right)$

$R_{\text {day }}=$ Amount of precipitation on day $\mathrm{i}$ $\left(\mathrm{mm} \mathrm{H}_{2} \mathrm{O}\right)$

$Q_{\text {surf }}=$ Amount of surface runoff on day i $\left(\mathrm{mm} \mathrm{H}_{2} \mathrm{O}\right)$

$E_{a} \quad=$ Amount of evapotranspiration on day $\mathrm{i}\left(\mathrm{mm} \mathrm{H}_{2} \mathrm{O}\right)$

$w_{\text {seep }}=$ Amount of water entering the vadose zone through percolation from the soil profile on day $\mathrm{i}\left(\mathrm{mm} \mathrm{H}_{2} \mathrm{O}\right)$

$Q_{g w} \quad=$ Amount of return flow on day i (mm $\mathrm{H}_{2} \mathrm{O}$ )

\section{SWAT model setup}

ArcSWAT is an extension of ArcGIS and therefore requires an input in the form of various maps, representing their individual class of data, which are then overlaid together so as to form a complete system incorporating a variety of parameters which might have an effect over the output. Figure 2 shows the work flow involved in setting up a SWAT model for simulation of runoff.

\section{SWAT model execution}

The DEM of the study area as shown in Figure 3 was used as a basic input for the model. The elevations in the area ranged from $255 \mathrm{~m}$ to $1703 \mathrm{~m}$ with the average elevation in the area being $461.56 \mathrm{~m}$. The soil map of the study area, as shown in Figure 4, indicated two units of dominant soil textures in the area, i.e., silt loam and loam. The land use map of the study area, as shown in Figure 5, indicated that most of the area was covered with ranged shrubs and grasses. The slope class map of the area, as shown in in Figure 6, indicated that most of the area had a gentle slope ranging from 3 to $10 \%$ while the overall slope of the area varied from 0.6 to $261 \%$. The DEM was used for stream definition and delineation. The soil map, land use map and slope class map were used for HRU analysis.

The simulation was done on a monthly timescale with rainfall as a basic weather input. The average monthly rainfall of Pindwara watershed for a time period of 2001 to 2012 is shown in Figure 7.

\section{Results and Discussion}

In the present work, the SWAT model simulation was carried out for a period of 12 years from 2001 to 2012 with the initial two years provided as the warm-up period. The results thus obtained have been presented and discussed in the ensuing sections.

\section{Annual hydrologic cycle}

The annual hydrologic cycle of the study area obtained from the simulation of the SWAT model is shown in Figure 8. SWAT simulated 
an average annual precipitation of $758.2 \mathrm{~mm}$ in the watershed out of which, $174.96 \mathrm{~mm}$ of surface runoff, $15.55 \mathrm{~mm}$ of lateral flow and $87.06 \mathrm{~mm}$ of return flow was generated. A weighted curve number of 78.66 was obtained for the entire watershed indicating a moderate runoff potential in the study area. It was found that only $37 \%$ of the total rainfall contributed to runoff generation. Also, $37 \%$ of the total runoff was estimated to flow as base flow while the remaining flow was surface runoff.

\section{Runoff estimation using SWAT}

From the SWAT simulation, runoff estimation was carried out on a monthly timescale for a period of 10 years from 2003 to 2012. The average monthly runoff thus estimated by SWAT is given in Table 1. It was found that the highest average monthly surface runoff occurred in the month of August. Significant amounts of runoff were estimated during the period of June to September which corresponds with the occurrence of high rainfall in that period due to monsoon season. Runoff generation was almost negligible for the all the months besides those under monsoon season. SWAT was also used to estimate runoff contribution from each land use class in the area as shown in Table 2. The highest and lowest surface runoff was generated in barren land and forested area respectively. The highest and lowest lateral flow occurred in forested area and barren land respectively.

\section{Comparison of SWAT simulated runoff and observed runoff}

The monthly runoff estimated from the simulation of the SWAT model was compared with the observed monthly runoff for a period of 8 years from 2003 to 2010. Figure 9 shows the comparison between the SWAT simulated monthly runoff and the observed monthly runoff.

It can be observed from Figure 9 that SWAT was not able to estimate high flows in most of the instances. This resulted in a low correlation between the simulated and the observed monthly runoff as shown in Figure 10.

Table.1 Average monthly runoff estimated by SWAT

\begin{tabular}{|c|c|c|c|c|}
\hline S. No. & Month & Rainfall $(\mathbf{m m})$ & Surface runoff $(\mathbf{m m})$ & Lateral flow $(\mathbf{m m})$ \\
\hline $\mathbf{1 .}$ & Jan & 1.26 & 0 & 0.1 \\
\hline $\mathbf{2 .}$ & Feb & 2.38 & 0.01 & 0.07 \\
\hline $\mathbf{3 .}$ & Mar & 1.03 & 0 & 0.05 \\
\hline $\mathbf{4 .}$ & Apr & 1.63 & 0 & 0.04 \\
\hline $\mathbf{5 .}$ & May & 5.07 & 0.02 & 0.06 \\
\hline $\mathbf{6 .}$ & Jun & 68.76 & 3.6 & 0.58 \\
\hline $\mathbf{7 .}$ & Jul & 266.35 & 63.2 & 3.38 \\
\hline $\mathbf{8 .}$ & Aug & 262.2 & 76.7 & 5.12 \\
\hline 9. & Sep & 126.96 & 27.75 & 4.17 \\
\hline $\mathbf{1 0 .}$ & Oct & 8.48 & 0.39 & 1.27 \\
\hline $\mathbf{1 1 .}$ & Nov & 13.75 & 3.28 & 0.45 \\
\hline $\mathbf{1 2 .}$ & Dec & 0.42 & 0 & 0.25 \\
\hline
\end{tabular}


Table.2 Hydrologic land use summary of Pindwara watershed

\begin{tabular}{|c|c|c|c|c|c|c|}
\hline S. No. & Land use & Area & CN & $\begin{array}{c}\text { Rainfall } \\
(\mathrm{mm})\end{array}$ & $\begin{array}{c}\text { Surface } \\
\text { runoff }(\mathrm{mm})\end{array}$ & $\begin{array}{c}\text { Ground water } \\
\text { flow (mm) }\end{array}$ \\
\hline 1. & Agriculture & 67.53 & 86.99 & 746.6 & 247.57 & 14.95 \\
\hline 2. & Barren land & 3.18 & 94 & 727.78 & 396.46 & 0.19 \\
\hline 3. & Urban + Mines & 57.14 & 82.51 & 696.26 & 203.32 & 12.25 \\
\hline 4. & Forested area & 38.95 & 73.51 & 751 & 159.54 & 163.5 \\
\hline 5. & Shrubland & 1226.13 & 78.09 & 762.64 & 170.2 & 110.37 \\
\hline
\end{tabular}

Fig.1 Map of the Pindwara watershed

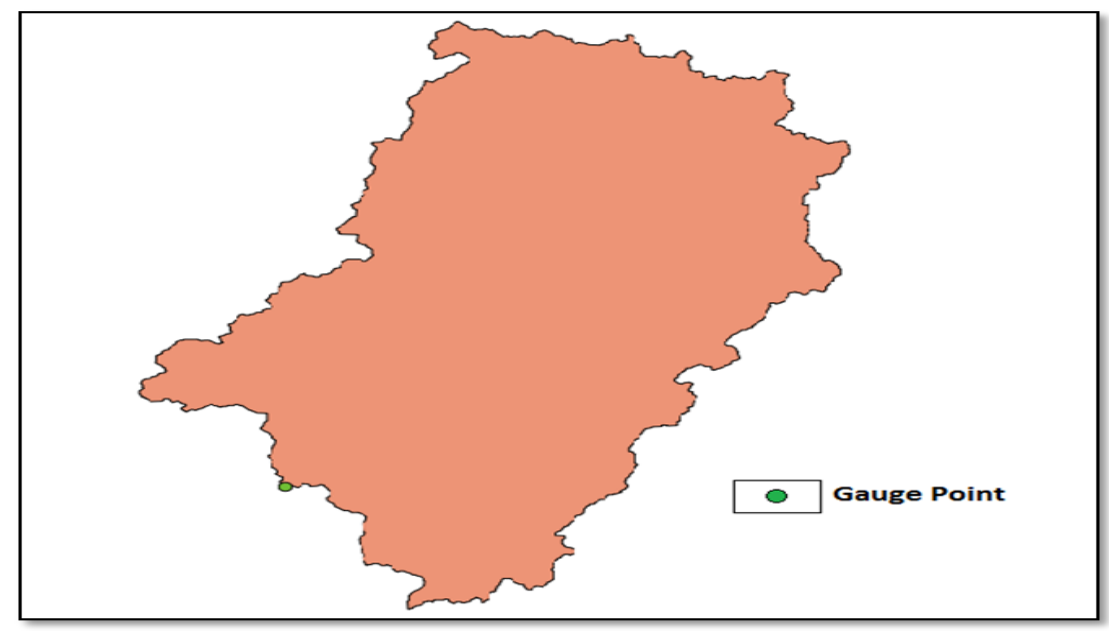

Fig.2 ArcSWAT work flow and processes

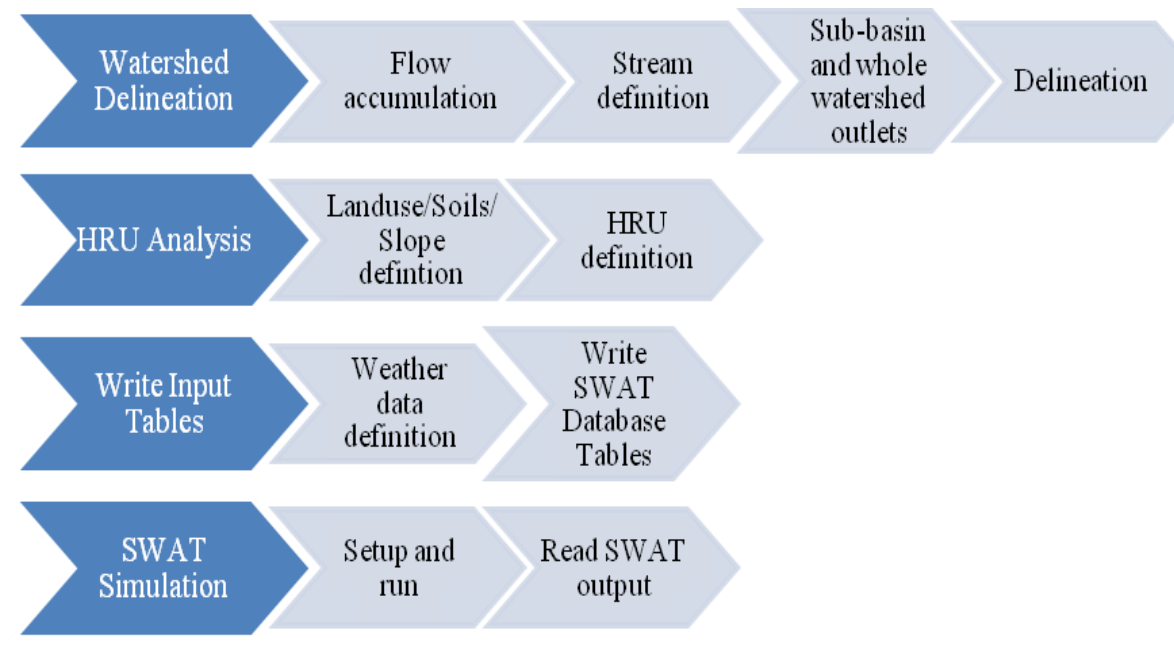


Fig.3 DEM of Pindwara watershed

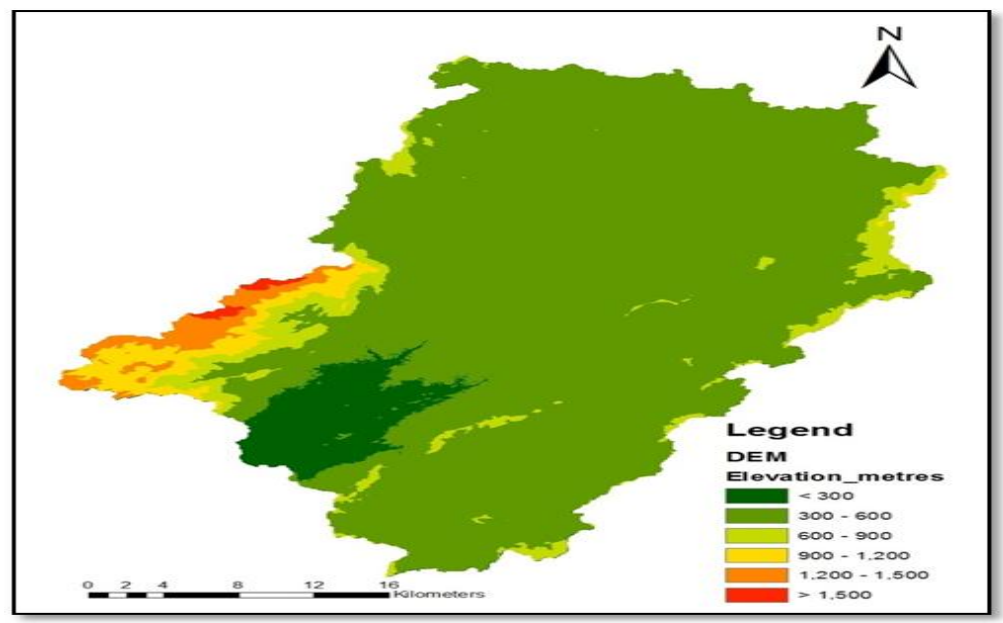

Fig.4 Soil map of Pindwara watershed

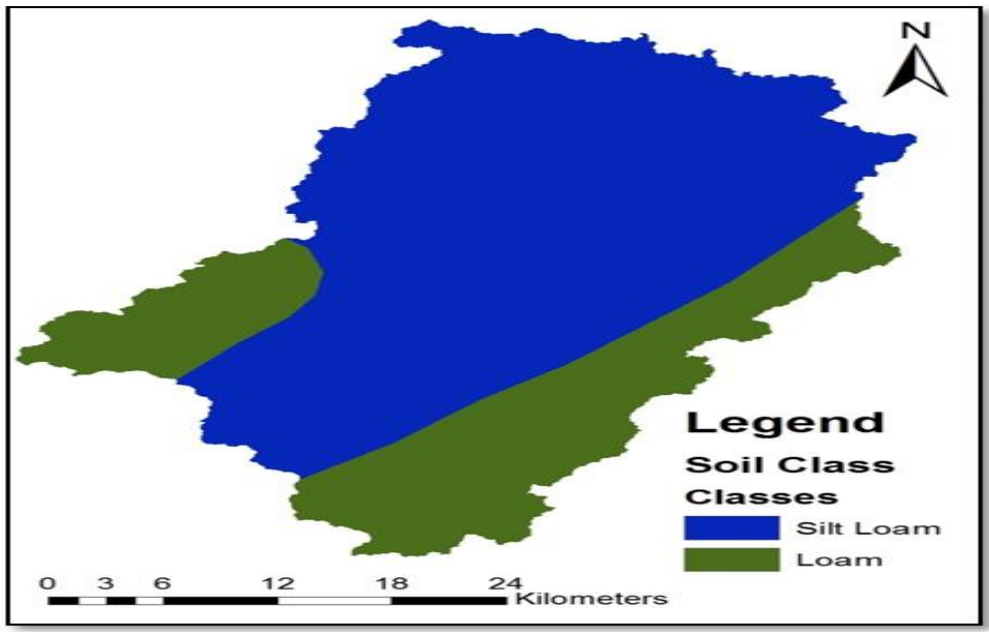

Fig.5 Land use map of Pindwara watershed

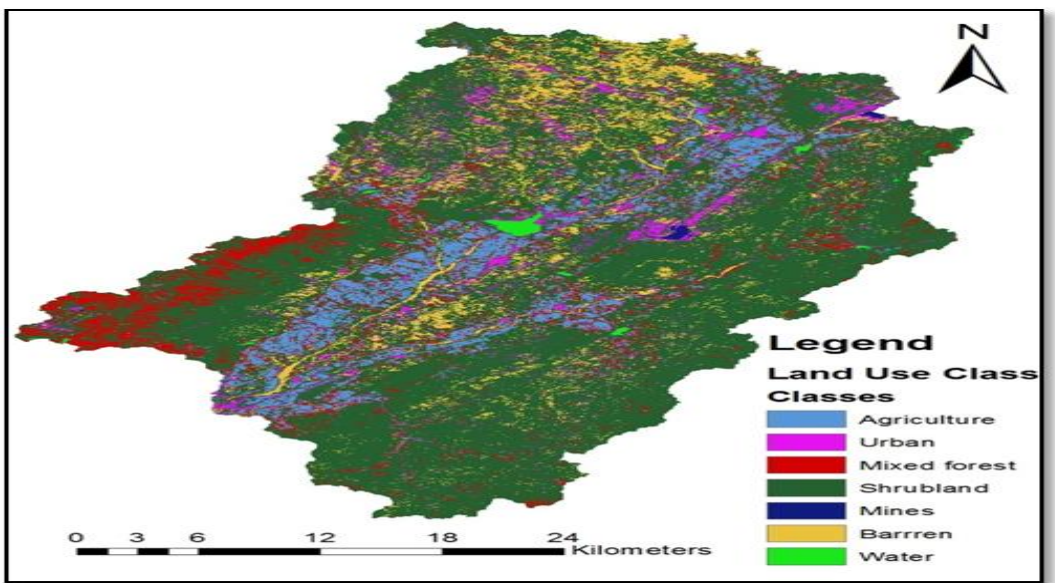


Fig.6 Slope class map of Pindwara watershed

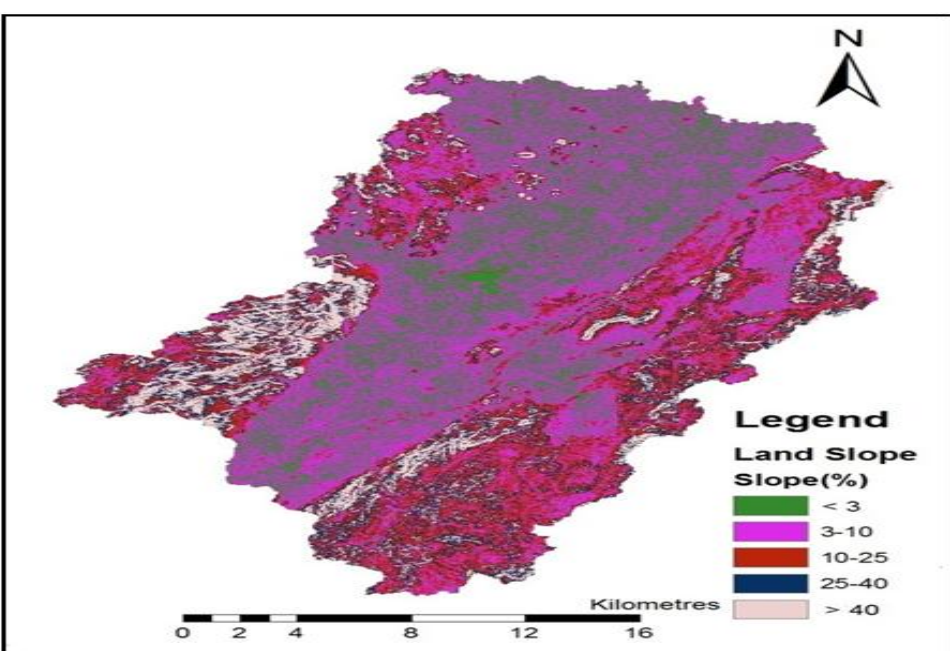

Fig.7 Average monthly rainfall in Pindwara watershed from 2001 to 2012

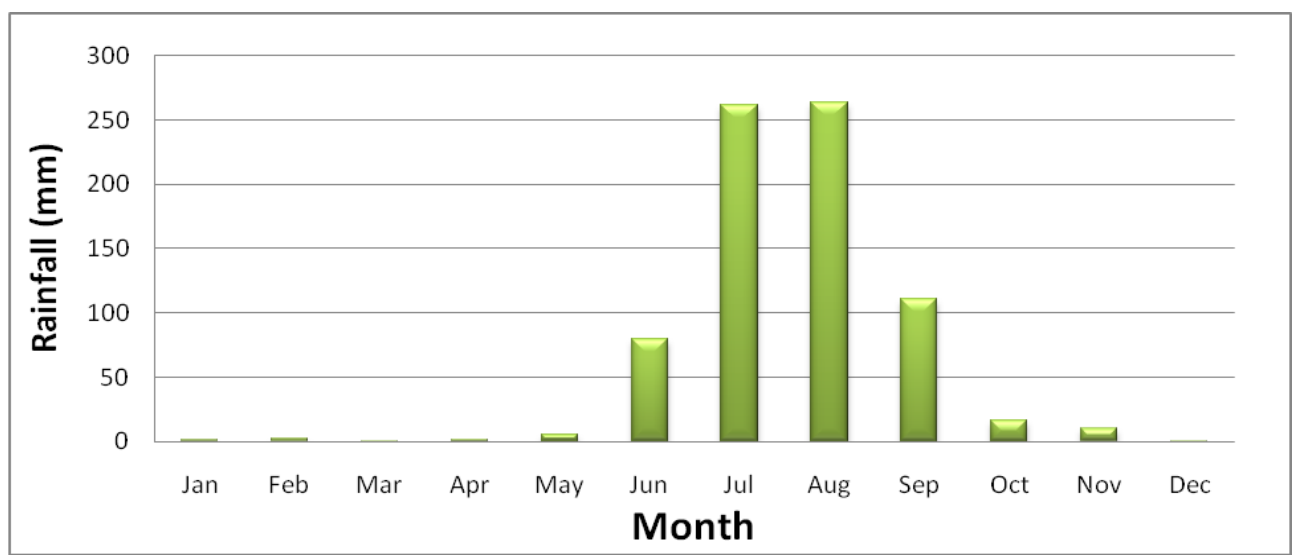

Fig.8 SWAT simulated annual hydrologic cycle of Pindwara watershed

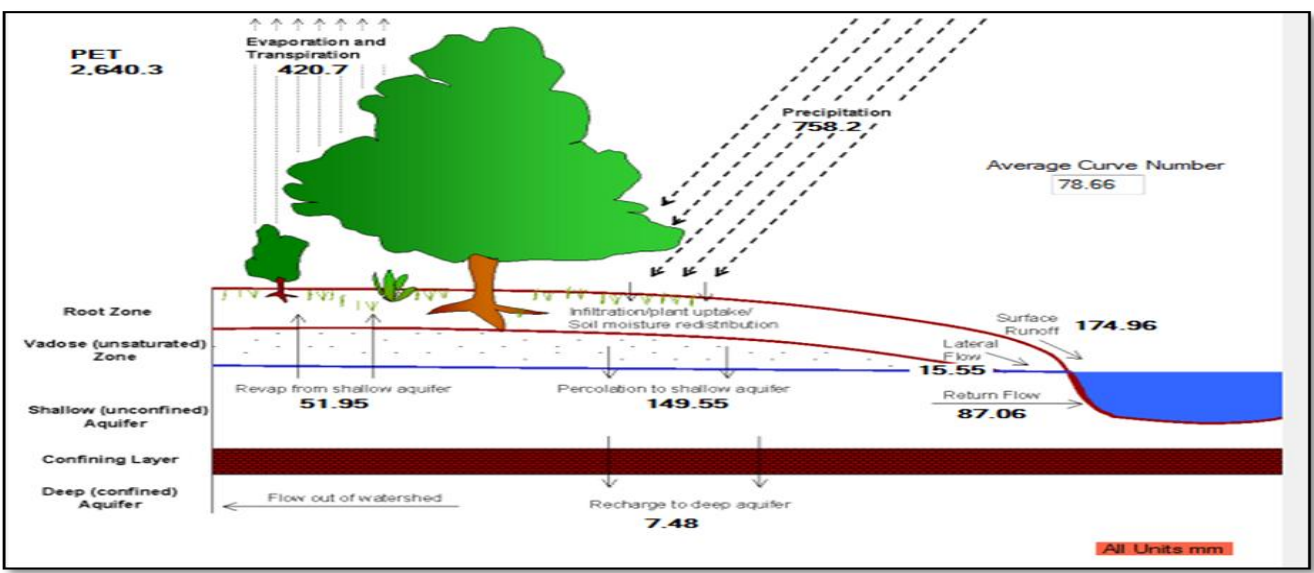


Fig.9 Comparison between the SWAT simulated and observed monthly runoff

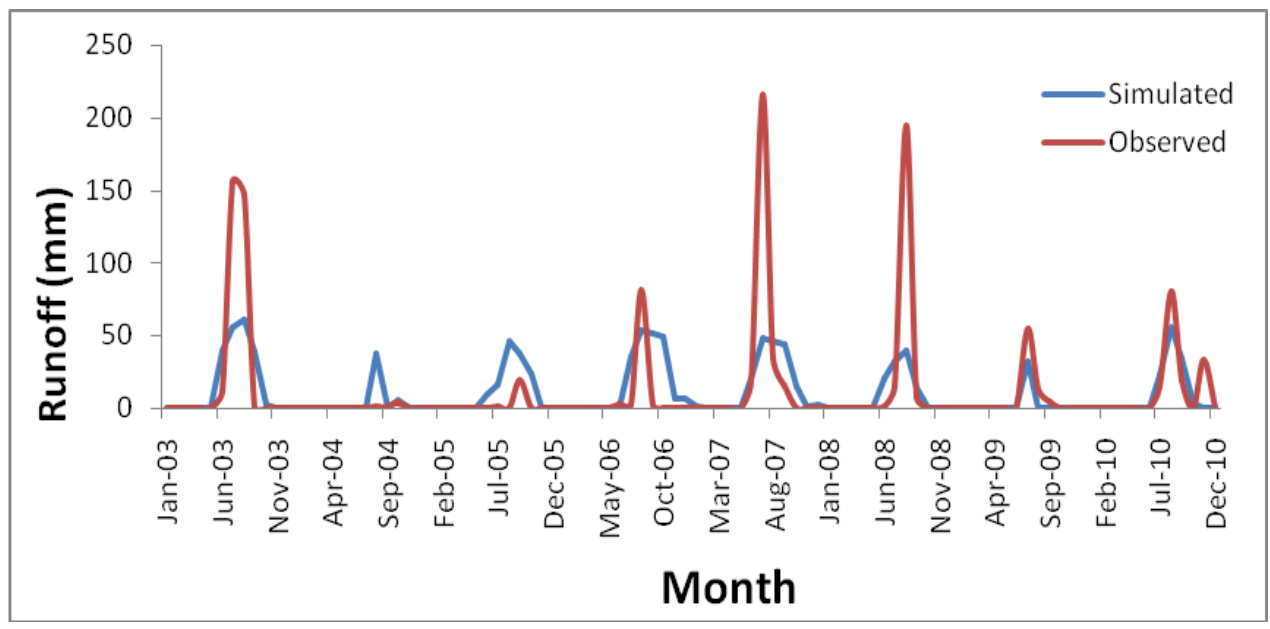

Fig.10 Correlation between SWAT simulated and observed monthly runoff

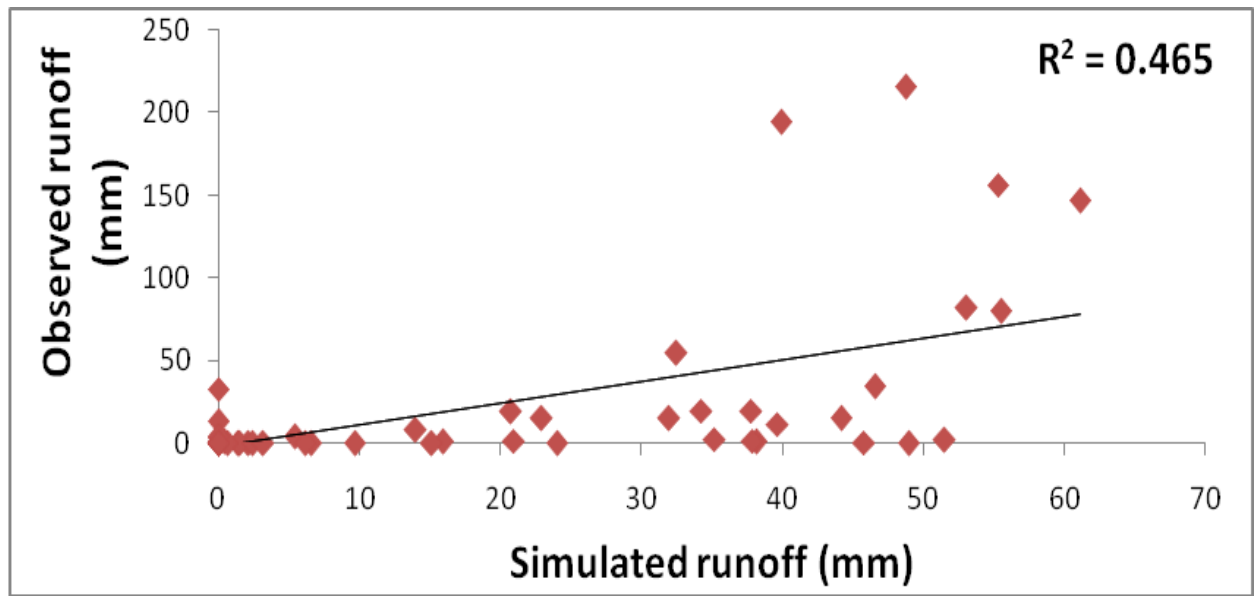

Coefficient of determination $\left(\mathrm{R}^{2}\right)$ and NashSutcliffe efficiency were selected as objective functions to evaluate the model performance. The $\mathrm{R}^{2}$ and NSE values for the model were obtained as 0.465 and 0.402 respectively. The obtained $\mathrm{R}^{2}$ and NSE values were below the acceptable limits and thus suggested a poor correlation between the simulated and the observed runoff. Qiu et al., (2012) conducted a study in Zhifanggou watershed located in a hilly-gullied region of China which was similar to the present study in terms of the terrain in the study areas, and managed to obtain acceptable correlation between the estimated and observed runoff however, the runoff was still underestimated as is the case in the present study. He suggested that the disparity between observed and simulated data most likely resulted from limitations of the existing SCS-CN-based methods implemented in the SWAT model for runoff estimation. Therefore, before using the model for field application, calibration of the model parameters according to literature and conditions of the study area must be done to obtain a better fit between the simulated and the observed values of runoff.

In conclusion, the present study revealed that the direct application of SWAT model for the 
estimation of runoff in the Pindwara watershed was not suitable. The runoff estimated using SWAT was very low and therefore, SWAT tended to underestimate runoff in the watershed. The correlation between the simulated runoff and the observed runoff was acceptable only for low values of runoff but the overall correlation was poor. The low values of objective functions $\mathrm{R}^{2}$ and NSE suggested poor fit of the model when compared against field conditions. The model required improvement via calibration and validation of the model using reasonable parameter ranges to obtain a better fit.

\section{Acknowledgement}

The first author is grateful to the faculty of Department of Soil and Water Engineering, CTAE, Udaipur, for being a constant source of encouragement, support and motivation whenever required during the course of this study.

\section{References}

Arnold, J.G., Srinivasan, R., Muttiah, R.S. and Williams, J.R. 1998. Large area hydrologic modeling and assessment part I: Model development. Journal of the American Water Resources Association. 34(1): 73-89.

Byakod, K., Shivapur, A.V. and Venktesh, B. 2017. Application of SWAT model for generating surface runoff and estimation of water availability for balehonnuru catchment area for Badhra river basin. International Research Journal of Engineering and Technology. 4(8): 1143-1148.

Easton, Z.M., Fuka, D.R., White, E.D., Collick, A.S., Ashagre, B.B., McCartney, M., Awulachew, S.B., Ahmed, A.A. and Steenhuis, T.S. 2010. A multi basin SWAT model analysis of runoff and sedimentation in the Blue Nile, Ethiopia. Hydrology and Earth System Sciences. 14(10): 1827-1841.

Lévesque, E., Anctil, F., van Griensven, A. and Beauchamp, N. 2008. Evaluation of streamflow simulation by SWAT model for two small watersheds under snowmelt and rainfall. Hydrological Sciences Journal. 53(5): 961-976.

Ngo, T.S., Binh N.D and Shrestha. R.P. 2015. Effect of land use change on runoff and sediment yield in Da river basin of Hoah Binh province, Northwest Vietnam. Journal of Mountain Science. 12(4): 1051-1064.

Patil, N.S., Raikar, R.V. and Manoj, S. 2014. Runoff Modelling for Bhima River using SWAT Hydrological Model. International Journal of Engineering Research \& Technology. 3(7): 923928.

Qiu, L., Zheng, F. and Yin, R. 2012. SWATbased runoff and sediment simulation in a small watershed, the loessial hillygullied region of China: capabilities and challenges. International Journal of Sediment Research. 27(2): 226-234.

Rosenthal, W.D., Srinivasan, R. and Arnold, J.G. 1995. Alternative river management using a linked GIShydrology model. Transactions of the ASAE. 38(3): 783-790.

Simić, Z., Milivojević, N., Prodanović, D., Milivojević, V. and Perović, N. 2009. SWAT-based runoff modeling in complex catchment areas Theoretical background and numerical procedures Journal of the Serbian Society for Computational Mechanics. 3(1): 38-63.

Srinivasan, R., Ramanarayanan, T.S., Arnold, J.G. and Bednarz, S.T. 1998. Large area hydrological modeling and assessment part II: Model application. 
Journal of the American Water Resources Association. 34(1): 91-101.

Tibebe, D., and Bewket, W. 2011. Surface runoff and soil erosion estimation using the SWAT model in the Keleta Watershed, Ethiopia. Land Degradation \& Development. 22(6): 551-564.

Van Liew, M.W., and Garbrecht, J. 2003. Hydrologic simulation of the little washita river experimental watershed using SWAT. Journal of the American Water Resources Association. 39(2): 13-26.

Xu, Z.X., Pang, J.P., Liu, C.M. and Li, J.Y. 2009. Assessment of runoff and sediment yield in the Miyun Reservoir catchment by using SWAT model. Hydrological Processes. 23(25): 36193630 .

\section{How to cite this article:}

Harsh Upadhyay, H.K. Mittal, Manjeet Singh and Hirapara, J.G. 2019. Application of SWAT Model for Estimation of Runoff in Pindwara Watershed and Assessment of its Feasibility. Int.J.Curr.Microbiol.App.Sci. 8(06): 3056-3065. doi: https://doi.org/10.20546/ijcmas.2019.806.364 